\title{
Antecedents to Students' Satisfaction of Higher Education Institutions: A Case Study of Brunei Darussalam
}

\author{
Chui Suan Hoh ${ }^{1, a}$, Shoukat I Khattak ${ }^{2, b,{ }^{*}}$ and Hui LI ${ }^{1, c}$ \\ ${ }^{1}$ Institute of Higher Education, Xiamen University, Xiamen, Fujian, China \\ ${ }^{2}$ School of Management, Xiamen University, Xiamen, Fujian, China

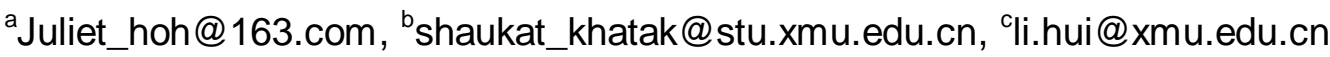 \\ ${ }^{*}$ Corresponding Author
}

Keywords: Student satisfaction, Brunei Darussalam, Job selection.

\begin{abstract}
With changing organizational demand for the multi-talent workforce, educational institutions have more to do than just impart knowledge. In parallel, policymakers are joining hands to address educational disparity with global initiative such as Education 2030 and United Nation Strategic Development Goals. Despite that, current research on factors predicting students learning satisfaction remains an area of limited research in Asia, particularly in Brunei Darussalam. To address this knowledge gap, the study explored factors that shape learning satisfaction of future workforce. The study analyzed data from 1048 student self-reports from 6 universities with a diverse student profile. As per current findings, students reported the level of learning satisfaction in the sequence (highest to lowest) from peer relationship, library resources, university policies, course curriculum, accommodation, administration services, lecturer teaching to lecturer guidance. Beyond uncovering dynamics of Brunei Darussalam's higher education characteristics, the study's findings add to current educational theory, in terms of identifying the complex schematics of factors that influence student learning satisfaction.
\end{abstract}

\section{Introduction}

The Brunei Darussalam National Education System for the 21st Century (SPN21) aims to produce citizens who are committed and able to contribute to the future growth, prosperity, and stability of the country. The satisfaction of students in higher education institutions plays a crucial role in improving student success rates and enhancing their marketability upon their entry into the job market. The long-term development framework for Brunei, set out in Brunei Vision 2035, makes education and human capital development key priorities [1]. Globally, universities use different investigative tools to assess and measure student feedback and implement various strategies to improve the quality of life of university students. Student satisfaction surveys are one of the essential tools used for this purpose. Unfortunately, Brunei has not yet carried out student satisfaction levels surveys at the national level to gauge student learning and development. Therefore, research into Brunei undergraduate university students' satisfaction is of great significance to the development of Brunei higher institutions. Consequently, this study aims to explore the main factors that affect the satisfaction of undergraduate students. Specifically, it will explore the following research questions.

(1) What are the factors of student learning satisfaction?

(2) What are the current situation of student learning satisfaction in Brunei?

(3) What factors do students perceive as important when selecting a job?

(4) What factors do students perceive their prospective employers believe important hiring factors?

\section{Literature Review}

Student satisfaction (here and after referred as "SS") is defined by Elliott and Healy [2] as a short-termed cognitive attitude and emotional feeling that result from a student's overall evaluation of their experience with the education services they received. Okun and Weir [3] defined SS as a cognitive assessment of the overall quality of college life and linked satisfaction to learning and development. More 
broadly, Giese and Cole [4] defined satisfaction as an emotional or cognitive response relating to a particular focus that occurs at a specific time. In simple terms, SS will be positive when actual performance meets or exceeds the student's expectations. Because SS allows for the prediction of student behavior [5], it is an important factor in measuring the quality of a learning approach and is a key factor in the success of learning programs [6]. Moreover, students are end-users, so their feedback regarding their satisfaction is valuable in improving the quality of education [7]. Studies show that student feedback is valid and reliable. Students' needs and expectations allow educational institutions to attract and retain quality students, as well as improve the quality of their programs. Because SS has become an important area for universities' performance indicators (e.g., feedback surveys), it is imperative for universities to listen carefully to what students are saying [8]. The concept of SS is an essential element for universities, which enables them to re-engineer their organization and deliver their services efficiently according to the needs and expectations of students [8]. Because quality has become a matter of vital importance in today's higher education, universities are now focused on the needs and expectations of the students, as well as providing resources and opportunities for the students' learning and development.

Astin [9] explained that the objective of higher education institutions is to support student development and provide knowledge. After entering the university, students gain experiences with their involvement in a university environment. Satisfied students are likely to be more knowledgeable, talented, competent and skillful than dissatisfied students. These qualities translate to success in the students' professional careers and lives. SS is an essential factor in the business of higher education [10]. When students are satisfied with the university's services, they can encourage the university to upgrade and improve its credibility and prestige, which in turn leads to an increase in the number of students [11]. SS can also be considered an indispensable objective for higher education institutions because of its potential favoured consequences [12]. Another factor that makes SS of particular importance to universities is that it has become a measure used to compile rankings and league tables [13]. All in all, SS is a multifaceted concept, which controls the students' subjective experiences throughout their educational life [14]. Many studies have been conducted with the aim of identifying the factors related to SS. According to Hearn [15], the two main factors that affect SS are whether a course is interesting or not, and the teaching style of the lecturer. Another important factor is the study environment [16]. Other studies have demonstrated that the high achieving students have higher satisfaction levels [17]. Factors associated with students' satisfaction are multi-dimensional and vary for each person and educational institution [18]. Factors that affect SS can be categorised into three main groups: personal, institutional, and psychosocial. Personal factors are related to student characteristics and variables and include age, ethnicity, part-time or full-time status, and student perception of institutional ability to provide an excellent intellectual environment [2]. Appleton-Knapp and Krentler further identified personal factors that influence SS: gender, temperament, preferred learning style, age, employment, and GPA [19].

\section{Theoretical Framework}

This study explores SS, student overall learning situation, development process, and the quality of campus life from a variety of perspectives from different stakeholders, including administrators, lecturers, and of course students themselves. This study has two specific purposes. Firstly, it considers the overall situation and the critical factors affecting undergraduate learning satisfaction within the universities of Brunei Darussalam. Secondly, it seeks to identify the differences, compare the input characteristics of students and focus on the job selection factor from the perspective of Brunei students. To achieve stated reserach objective, this study used the Input-Environment-Output (IEO) model theory [20] and student involvement theory [21]. As seen in Figure 1, Astin's [20] model depicts three dimensions namely input, environment and output. According to Astin [22], the assessment of higher education are captured by arrow $\mathrm{B}$, which indicates the effects of environmental variables on outcome variables, while student inputs indicated by arrows $\mathrm{A}$ and $\mathrm{C}$ can be related to both outputs and environments. Different students might choose different types of educational environments. Therefore, inputs can interconnect to both outputs and environments, which means input variables might affect the observed relationship between both environment and outputs variables. The major purpose of the application of this model is to decide how educational environments can be formed to increase the development of student [22]. 


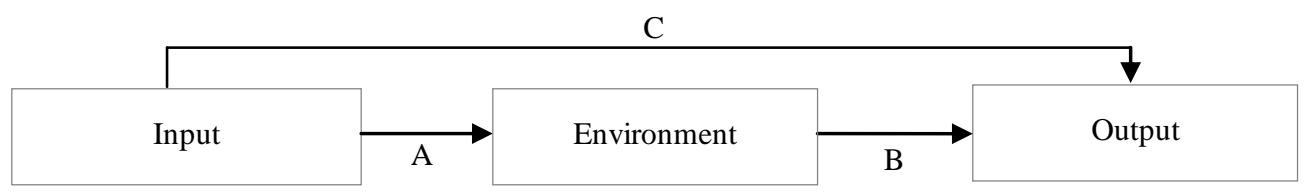

Fig. 1 Conceptual framework for student learning satisfaction

\section{Methodology}

\section{Participants and Procedures}

This study is partly based on a modified English version of a questionnaire entitled National College Students Survey (NCSS) from the Institute of Higher Education, Xiamen University, China. The questionnaire was developed by Professor Shi Qiuheng and administered as the primary tool to collect the quantitative data. His project, which has successfully been run on a large-scale basis since 2011, aims to provide support for decision making and thus improving the lives of undergraduate students in China [23, $24,25]$. Students were asked to rate as accurately as possible their degree of satisfaction and their level of agreement on a six-point Likert scale with a continuum ranging from students might choose different types of educational gain experiences with their involvement in a university environment". Brunei currently has six higher learning institutions, namely Universiti Brunei Darussalam (UBD), Universiti Teknologi Brunei (UTB), Universiti Islam Sultan Sharif Ali (UNISSA), Kolej Universiti Perguruan Ugama Seri Begawan (KUPUSB), International Graduate Studies College (IGS), Laksamana College of Business (LCB) in Brunei. Out of these six institutions, four are national public universities: UBD, UTB, UNISSA, and KUPUSB. IGS and LCB are private colleges. UBD and UTB are under the administration of the Ministry of Education (MoE) whereas UNISSA and KUPUSB are under the Ministry of Religious Affairs (MoRA). Out of 1,200 questionnaires, 1121 were returned (response rate $=93.4 \%$ ), while 1048 were considered usable.

\section{Results and Findings}

\section{Reliability and Validity of Survey Instruments}

The Kaiser-Meyer-Olkin (KMO), Bartlett's Test of Sphericity and scree test were used to determine the suitability of the undergraduate SS questionnaire. The results of the analysis indicate a KMO statistic of 0.974 , which is higher than 0.60 and near to 1 and therefore is valid for the factor analysis. The Bartlett's test of sphericity chi-square value is 40437.925 with 561 degrees of freedom at 0.001 level of significance, which indicates that there is a well-built association among the items. Through the Principal components factor analysis (PCA) by using a Varimax rotation, factors extracted derived from the total variance in the correlation matrix can be applied. There were 42 items in the revised English version of the National College Student Survey and after exploring several times, 8 items were removed with less than 0.40 factor loading and 34 items retain which were fit well with each factor. These 34 items are reduced to 8 factors which have correlation values ranging from .911 to .414 , which account for $82.052 \%$ of the total variance in student learning satisfaction. After using the factor analysis, Cronbach alpha coefficient was applied to the instrument to determine the internal consistency. An alpha coefficient of more than 0.90 is classified as highly reliable $[26,27]$. The results indicates that all these sub-dimensions of the questionnaires are higher than 0.80 .

\section{Demographic and Institutional Antecedents affect Overall Student Learning Satisfaction}

An initial view of eight factors showed that the overall learning satisfaction among student was high (77.51\%). The satisfaction rankings (from highest to lowest) on 8 factors are as follows: peer relationship $(85.73 \%)$, library resources $(85.62 \%)$, university facilities $(81.35 \%)$, course curriculum $(78.52 \%)$, accommodation (78.37\%), administrative services (76.27\%), teaching $(71.98 \%)$ and lecturer guidance 
(71.68). Table 1 shows that there are no statistically significant differences among gender mean scores on overall student satisfaction $(\mathrm{t}=1.701)$. The mean score for the male student is 4.90 with a weighted percentage of $78.08 \%$; the mean score for the female is 4.85 with a weighted percentage of $76.93 \%$. This shows that male students are more satisfied with their overall learning experiences than female students. For accommodation, students who live on campus have significantly higher means of university experience satisfaction compared to students who live off campus. There are statistically significant differences among accommodation mean scores on overall student satisfaction $(\mathrm{t}=20.69, \mathrm{p}<.001)$. The mean score for students who live on campus is 5.03 with a weighted percentage of $80.68 \%$; the mean score for students who live off campus is 4.81 with a weighted percentage of $76.27 \%$. This show that students who live on campus are most satisfied with their overall learning experiences than students who live off campus.

Table 1 Overall satisfaction based on demogragics and institutional variables

\begin{tabular}{|c|c|c|c|c|c|c|c|}
\hline & & $\mathrm{N}$ & Mean & SD & $\mathrm{t}$-value & Sig. & $\begin{array}{c}\text { Weighted } \\
\text { Satisfaction \%age }\end{array}$ \\
\hline \multirow[t]{2}{*}{ Gender } & Male & 528 & 4.90 & .67 & 1.701 & .192 & 78.08 \\
\hline & Female & 520 & 4.85 & .75 & & & 76.93 \\
\hline \multirow[t]{3}{*}{ Accommodation } & On Campus & 296 & 5.03 & .54 & $20.69 * * *$ & .000 & 80.68 \\
\hline & Off-Campus & 752 & 4.81 & .76 & & & 76.27 \\
\hline & & & & & F-stats & & \\
\hline \multirow[t]{4}{*}{ Age Group } & Under 20 & 599 & 4.99 & .45 & $45.31 * * *$ & .000 & 79.72 \\
\hline & $20-21$ & 260 & 4.99 & .71 & & & 79.83 \\
\hline & $22-23$ & 101 & 4.45 & 1.09 & & & 69.00 \\
\hline & Over 24 years old & 88 & 4.27 & 1.06 & & & 65.37 \\
\hline \multirow[t]{4}{*}{ Year of study } & 1st-year & 270 & 4.75 & .58 & $8.73 * * *$ & .000 & 75.04 \\
\hline & 2nd-year & 287 & 4.85 & .62 & & & 77.04 \\
\hline & 3rd-year & 154 & 4.80 & .81 & & & 76.00 \\
\hline & 4th-year & 337 & 5.03 & .81 & & & 80.59 \\
\hline \multirow{7}{*}{ University Attended } & UBD & 312 & 4.93 & .66 & $7.23 * * *$ & .000 & 78.61 \\
\hline & UTB & 265 & 4.99 & .51 & & & 79.89 \\
\hline & UNISSA & 144 & 4.79 & .70 & & & 75.83 \\
\hline & KUPUSB & 88 & 4.49 & 1.09 & & & 69.79 \\
\hline & IGS & 131 & 4.78 & .85 & & & 75.59 \\
\hline & LCB & 101 & 4.98 & .60 & & & 79.69 \\
\hline & Others & 7 & 4.74 & .85 & & & 74.79 \\
\hline \multirow[t]{6}{*}{ Academic Grades } & Very Poor & 1 & 4.00 & & $40.25^{* * *}$ & .000 & 60.00 \\
\hline & Poor & 5 & 3.56 & 1.02 & & & 51.18 \\
\hline & Pass & 42 & 4.08 & 1.08 & & & 61.67 \\
\hline & Credit & 396 & 4.66 & .81 & & & 73.17 \\
\hline & Distinction & 481 & 5.04 & .49 & & & 80.76 \\
\hline & High Distinction & 123 & 5.27 & .42 & & & 85.43 \\
\hline
\end{tabular}

Note: $\mathrm{N}=1048 . *=\mathrm{p}<0.05, * *=\mathrm{p}<0.01, * * *=\mathrm{p}<0.001, \mathrm{NSD}=$ no significance

By age group, students aged under 20 and between 20-21 years old have the highest mean of satisfaction with university experience compared to students between 22-23, and over 24 years old. There are statistically significant differences among age group with regard to overall student satisfaction $\mathrm{F}=$ $45.31, \mathrm{p}<.001$. These results suggest that younger students are most satisfied with their overall learning experiences than older students. By level of study, $4^{\text {th- }}$ year students have significantly higher satisfaction with university experience compared to other groups. There are statistically significant differences between class year in university with regard to overall student satisfaction $(F=8.73, p<.001)$. The results indicate that seniors, sophomores, and juniors experience more overall student satisfaction than first-year students. Finally, no significant differences were found between different study majors $(\mathrm{F}=1.183)$. Health has the highest weighted percentage at $80.21 \%$, followed by Business \& Administration at $78.53 \%$, Computing at $78.52 \%$, and Arts \& Humanities at 78.38\%. Illustration Design with Animation, Higher National Diploma, and Advanced Diploma have the lowest weighted percentage at $63.92 \%$, followed by 
Law at $73.96 \%$, and Education at $74.21 \%$. However, the weighted percentage for some majors do not significantly differ in the Games-Howell test. Likewise, there are statistically significant differences among different university attended mean scores on overall student satisfaction $(\mathrm{F}=7.23, \mathrm{p}<.001)$. UTB has the highest weighted percentage at $79.89 \%$, followed by LCB (public university) at $79.69 \%$, UBD at $78.61 \%$, and UNISSA at $75.83 \%$. On the other hand, KUPUSB has the lowest weighted percentage at $69.79 \%$, followed by other universities (UK, Australia, Malaysia, Singapore higher institutions) at $74.79 \%$ and IGS (public university) at $75.59 \%$. Moreover, there are statistically significant differences among current university academic grade mean scores on overall student satisfaction $(\mathrm{F}=40.25, \mathrm{p}<.001)$. "High Distinction" has the highest weighted percentage at $85.43 \%$, followed by "Distinction" at $80.76 \%$, "Credit" at 73.17\%, "Pass" at 61.67\%, "Very Poor" at $60.00 \%$, and "Poor" at $51.18 \%$. These results suggest that students who do well academically in university are more satisfied with their learning experiences than students who do poorly. Additionally, there are statistically significant differences among students' pre-university grade mean scores on overall student satisfaction $(\mathrm{F}=25.15, \mathrm{p}<.001)$. "High Distinction" has the highest weighted percentage at $85.52 \%$, followed by "Distinction" at $80.61 \%$, "Credit" at 76.67\%, "Pass" at 70.99\%, "Poor" at 59.12\%, and "Very Poor" at 51.83\%. Similar to grades achieved in university, these results suggest that students who have done well academically pre-university are more satisfied with their learning experiences in university than students who have done poorly.

\section{Student Perspective: Career Choices, Job Selection and Hiring Decision}

According to the survey results, 87.9 percent of students reported that if they had the chance to start over again, they would go to the same university, whereas 12.1 percent of students would go for another university. 58.9 percent of students reported that after graduation, they would prefer going to work; 40.7 percent of students would prefer to further their studies, and 0.4 percent of students were undecided. 56.3 percent of students (590 students) would prefer to work in the public sector; 17.2 percent of students (180 students) would prefer to work in the private sector; 25.6 percent of students (268 students) planned on starting their own small business; and $1 \%$ students were undecided. Based on the data analysis, the overall situation of job selection satisfaction can be collected from the mean score of 3.87 with the weighted percent of 57.45. The highest mean score for undergraduate student job selection was social status, followed by the student's interest in the job and less stressful jobs. The lower mean score was high salaries, followed by a contribution to society. This contrasts with China's survey results in 2016 which showed that Chinese college students cared most about their interest in the job, followed by high salaries and less stressful jobs; social status and contribution to society are relatively insignificant [28]. The probable reasons for the significant differences in work considerations between the citizens of the two countries are related to the differences in economic development, population, social environment and education policy. For hiring decision, the mean score is $4.44(68.86 \%)$. Students ranked factors like GPA/grades and performance in the interview to be extremely important when it comes to deciding whether or not they would be hired, while they did not consider their major/discipline and resume to be important.

\section{Discussion}

There are eight aspects of SS in the exploratory factor analysis. These attributes were used in previous research by Astin and other scholars $[15,16,17,18,19,29]$. The eight factors are the basic features of undergraduate's learning satisfaction, which is significant to the training goal and development direction of undergraduate students. Exploratory factor analysis of these eight factors provides a basis for the Brunei government to formulate policy, manage universities, and make decisions-allowing for the improvement of the quality of higher education and the cultivation of outstanding citizens. On the first tier, the students are satisfied with three factors namely peer relationship, library resources and learning environment, university policies and facilities. On the second tier, the students are moderately satisfied with two factors: course curriculum and accommodation. On the third tier, the students are dissatisfied with the services, lecturer teaching and student's guidance. Moreover, Elliott and Shin [8] specified that teachers' teaching and students' guidance have a greater impact on student learning outcomes. Similar to this study, many college students have made higher demands on these aspects. From results, we found that the lecturer teaching and students' guidance have smaller satisfaction level compared to other variables. 
Ramsden [30] demonstrated that students are uniquely qualified to judge teaching quality because they see a great deal of teaching and can convincingly distinguish good teaching from bad teaching. As a result, large research literature has been produced in the area of student evaluation of teaching. Hooper [31] stated students are the recipients of a teacher's interventions and the only people who can provide feedback on their teacher's performance. Therefore, he suggested that university students' experience and evaluation should be integrated into the assessment of university teaching [32]. Therefore, the students' satisfaction has to be improved in Brunei's universities, especially on the issues of lecture teaching and students' guidance. To explore the differences in satisfaction as it relates to different variables, the T-Test and ANOVA were used. Significant differences in satisfaction were found as it relates to the following variables: accommodation, age, year of study, university, academic grades in university, pre-university academic grades, health condition, and monthly expenditure. On the other hand, the study found no significant differences in satisfaction as it relates to gender, the field of study and nationality.

Finally, for job selection, social status was the most important followed by interest in job satisfaction, easy work with less stress, higher salary and contribution to society. As for student perspective on prospective employer's value on hiring decision, GPA/grades were the most important followed by interview performance, working experience, recommendation, university attended, major/discipline and resume. The results found that students were taking up the challenge to prepare themselves with an innovative mindset on entrepreneurship with their strong GPA/grades. Today, as the government is calling for diversification due to the falling oil price, the mandate of training the next generation of entrepreneurs has been significant. The government has supported them to explore careers outside of the country so that they could gain valuable experience and then return one day to serve Brunei

\section{Conclusion}

Education is an essential and rewarding investment expressed in multiple ways. In Brunei, educational institutions are willing to provide quality services in the hopes of improving education. To make institutions more progressive and effective, knowledge of students and academic preferences is crucial. Higher education institutions should engage with the needs and expectations of their students, and continuously improve their abilities to meet those needs and expectations. Based on the results of this study, several recommendations can be drawn for the stakeholders of higher education in Brunei, such as the Brunei Government, Ministry of Education, as well as university faculty and staff, for the betterment and further development of higher education in the country. These recommendations are as follows. First, the stakeholders should learn from global experience by implementing successful outcomes into the local education system, while forging a unique brand of higher education that suits the particular environment of Brunei at the same time. Universities should aim to stimulate student interest and potential by engaging in innovative teaching methods and continuously strengthening pedagogical approaches. In this regard, the training and recruitment of higher education personnel are very important. Universities should also pay attention to the factors of SS, in order to improve the quality of higher education, improve teaching quality, and enhance the student's employability. Second, the analysis of the structure of overall student learning satisfaction can be instrumental in improving education. The higher education resource allocation committee and higher education managers in Brunei should focus on improving and optimizing higher education policy because the development of education provides an important foundation for all citizens. Universities should take student satisfaction and student needs into consideration to propel Brunei higher education into greater significance. This implies that improving library and campus learning environment, consulting services, financial support, and other campus facilities can enhance student satisfaction. Finally, there needs to be more focus on meeting the needs of students from different backgrounds. This study has identified differences in SS about student background. Universities need to support students from all backgrounds and ensure that all students can maximize their potential and prepare themselves for their future to the best of their ability, regardless of students' backgrounds. 


\section{References}

[1] Ministry of Education. The Ministry of Education Strategic Plan 2018-2022, Bandar Seri Begawan, Ministry of Education https://www.moe.edu.bn/MOE\%20Strategic\%20Plan\%202018\%20-\%202022\%20Layout.pdf.

(2018),

[2] Elliott, K. M., \& Healy, M. A., Key factors influencing student satisfaction related to recruitment and retention , Journal of Marketing for Higher Education (2001), 10(4), 1-11.

[3] Okun, M. A., \& Weir, R. M., Towards a judgment model of college satisfaction, Educational Psychology Review (1990), 2(1), 59-76.

[4] Giese, J. F., \& Cole, J., Defining consumer satisfaction, Academy of Marketing Science Review, (2000), 1(1), 1-22.

[5] Olsen, L.L., \& Johnson, M.D., Service equity, satisfaction, and loyalty: From transaction-specific to cumulative evaluations, Journal of Service Research (2003), 5(3), 184-195.

[6] Marsh, H.W., Students' Evaluations of University Teaching: Research Findings, Methodological Issues, and Directions for Future Research, International Journal of Educational Research (1987), 11, 253-388.

[7] Williams, J., The student satisfaction approach: Student feedback and its potential role in quality assessment and enhancement, Presented in $24^{\text {th }}$ EAIR Forum, Prague (2002), 8-11 September 1, 77-82.

[8] Elliott, K.M., \& Shin, D., Student satisfaction: An alternative approach to assessing this important concept, Journal of Higher Education Policy and Management (2002) , 24, 197-209.

[9] Astin, A. W., Student involvement: A developmental theory for higher education, Journal of College Student Development (1999), 40(5), 518-529.

[10] Overbaugh, R. C., \& Nickel, C. E., A comparison of student satisfaction and value of academic community between blended and online sections of a university-level educational foundations course, The Internet and Higher Education (2014), 14(3), 164-174.

[11] Marzo-Navarro, M., Pedraja-Iglesias, M., \& Rivera-Torres, M. P., Measuring customer satisfaction in summer courses, Quality Assurance in Education (2005), 13(1), 53-65.

[12] Tamer H. Elsharnouby, Student co-creation behaviour in higher education: the role of satisfaction with the university experience, Journal of Marketing for Higher Education (2015), Vol.25, No.2, 238-262, http://www.tandfonline.com/doi/full/10.1080/08841241.2015.1059919.

[13] Wilkins, S., \& Balakrishnan, M.S., Assessing student satisfaction in transnational higher education, International Journal of Educational Management (2013), 27(2), 143-156.

[14] Ming Cheng, Quality in Higher Education: Developing a Virtue of Professional Practice, Sense Publishers, UK, (2016).

[15] Hearn, J., Determinants of college student's overall evaluations of their academic programs, Research in Higher Education Journal (1985), 23(4), 413-437.

[16] Miles, S., Swift, L., Leinster, J., The Dundee Ready Education Environment Measure (DREEM): A review of its adoption and use, Medical Teacher (2012), 34(1), 620-634.

[17] Morstain R., Analysis of students' satisfaction with their academic program, Journal of Higher Education (1977), 48(1), 1-16.

[18] Lee, G., Jolly, N., Kench, P., Gelonesy, B., Factors related to student satisfaction with the university, University of Sidney Faculty of Health Sciences, Sidney( 2000). 
[19] Pascarella, E., \& Smart, J., Impact of intercollegiate athletic participation for African American and Caucasian men: Some further evidence, Journal of College Student Development (1991), 32(3).

[20] Astin, A.W., "What matters in college?, Four critical years revisited, San Francisco: Jossey-Bass, (1993).

[21] Astin, A. W., Involvement in learning revisited: Lessons we have learned, Journal of College Student Development (1999), 40(5), 587-598.

[22] Astin, A. W., Assessment for excellence: The philosophy and practice of assessment and evaluation in higher education, New York: American Council on Education: Macmillan; Toronto: Collier Macmillan; New York: Maxwell Macmillan (1991), 1-335.

[23] Shi Qiuheng, Wang Yashan, Research on National College Student Survey, Educational Science Publishing House, China (2015), ISBN: 978-7-51910-123-7.

[24] Shi Qiuheng, Wen Jing. The Construction of Logic Model for Evaluating Learning Satisfaction of College Students, College Education Science (2013), Vol.04, 53-60.

[25] Shi Qiuheng, Gulzar Ali Shah Bukhari, An Empirical Research on Student Satisfaction of Higher Education Institutions in Pakistan, Education Research (2015), No.425,124-135, No. 6.

[26] Julie Pallet, SPSS Survival Manual, $4^{\text {th }}$ edition, National Library of Australia, www.librariesaustralia.nla.gov.au (2011), ISBN 9781742373928.

[27] Huck, S., Reading statistics and research, $6^{\text {th }}$ edition. Boston, MA: Person Education (2012).

[28] Shi Qiuheng, A Survey of College Students' Learning Conditions - Based on 6 Years of National Undergraduate Education Survey Data, Annual Meeting of the Chinese Higher Education Society, Nanning, Guangxi, China, 28-30 October 2016.

[29] Astin, A. W., Four Critical Years: Effects of College on Beliefs, Attitudes, and Knowledge, San Francisco: Jossey-Bass, Inc., Publishers (1997), 1-30.

[30] Ramsden, P., A performance indicator of teaching quality in higher education: The Course Experience Questionnaire, Studies in Higher Education (1991), 16, 129-150.

[31] Hooper, T., Evaluating teaching and learning: A practical handbook for colleges, universities and the scholarship of learning, by David Kember and Paul Ginns, Higher Education Research \& Development (2012), 31(5), 748-750.

[32] Jianpeng Guo, Lingyan Yang, Qiuheng Shi, Effects of Perceptions of the Learning environment and approaches to learning on Chinese undergraduates' Learning, Studies in Educational Evaluation, (2017) 55, 125-134, https://www.sciencedirect.com/science/article/pii/S0191491X17300019. 